\title{
SOBRE AS CRIANÇAS-PLANTA: O CUIDAR E O SEDUZIR NO PARENTESCO JARAWARA
}

\author{
Fabiana Maizza
}

O estrangeiro que chega à aldeia Jarawara pela primeira vez ${ }^{1}$ — em meio à curiosidade que marca encontros como este, o alívio por descansar após a longa e desconfortável caminhada e a alegria de encontrar uma aldeia tão bonita — ouve na fala discreta das pessoas o vocábulo amosákê marcando o desfecho de toda conversa. Trata-se de um verbo, namosá/amosá (a depender da oração), que abrange uma série de ideias referentes aos feitos que deixam algo ou alguém mais bonito: renovar, limpar, refazer, consertar, transformar. Bonito não apenas em termos de beleza, mas também no sentido de "certo", "bom", "boa", "bem feito", "renovado", "do jeito que deve ser".

Há uma grande preocupação das pessoas em deixar tudo à sua volta "bonito" e "certo" (amosákê). De forma a ilustrar esta ideia, lembro que as casas devem ter seus arredores capinados, retiram-se periodicamente as ervas daninhas dos roçados, e a aldeia está sempre asseada, marcando de maneira contrastante sua diferença com a floresta - tal como podemos encontrar em outros povos ameríndios como, por exemplo, os Piaroa (Overing 1999). As pessoas se visitam apenas quando estão limpas e perfumadas — e só assim aceitam posar para fotos. As uniões matrimoniais devem ser "certas", com os cônjuges apropriados. A comida deve ser gostosa e nutritiva. Os filhos devem obedecer aos pais. Tudo deve ser novo: as madeiras das casas, os barcos, as roupas, as pessoas. Quase como se o namosá exagerasse um ideal do "viver bem" (Gow 1997); uma estética jarawara da produção do novo... do belo, do certo.

O namosá mobiliza referências, afetos, sentimentos, remetendo a um conjunto de conceitos que discutirei ao longo deste ensaio, como "gostar"/"seduzir" (nofá), "cuidar" (narifá) e "criar" (nayaná). São ideias centrais da socialidade jarawara, que não se limitam às relações entre humanos, mas se estendem como formas de experiência a praticamente todos os tipos de seres do cosmos, particularmente às plantas.

O que me proponho a discutir aqui, se bem me lembro, foi despertado quando um de meus amigos, Wero, me contou uma história que ouvira em 
um canto de um xamã. A narrativa versava sobre a morte do primo deste meu amigo, destacando-se o momento em que "almas" (abono) de plantas do roçado do falecido vieram buscá-lo para levá-lo ao nemê - a terra dos mortos, a camada superior. ${ }^{3}$ Wero insistiu no fato de essas "almas" (abono) serem filhas de seu primo morto a quem vinham buscar, e que, por isso, eram suas "sobrinhas" (bitimi). Ao falar de tal narrativa com outro amigo, Bibiri, que me ajudou a traduzi-la, deparei-me diretamente com aquilo que me estava sendo dito por diferentes pessoas desde minha primeira vez em campo: as plantas, as almas (abono) das plantas são "filhos de verdade" (okatao yokaná) dos Jarawara. Eu me via diante de algo que não apenas tinha dificuldade em compreender em razão de meus parcos recursos linguísticos, mas também sequer concebia de maneira satisfatória. ${ }^{4}$

Aproximadamente 200 pessoas se definem como Jarawara, as quais formariam um grupo em meio a uma constelação de grupos que moram nas proximidades do Médio Purus, relacionam-se entre si e pertencem a uma mesma família linguística, Arawá. Nas etnografias arawá há duas breves menções ao que foi dito acima. A primeira, quando Bonilla afirma que os Paumari chamam de filhos as plantas que cultivam, mencionando também os "parentes vegetais" (2007:294-295), sem mais detalhes. A segunda, em Kroemer (1994:142), que relata que entre os Zuruaha existiriam seres que morariam no "submundo", os kurimie buadahaze, e que se relacionariam cada qual com uma espécie de planta, de que são "donos". A importância das plantas, das palmeiras aparece igualmente em outros grupos do Sudoeste amazônico, como os Kaxinawá (McCallum 1996), os Kanamari (Costa 2007) e os Matses (Matos 2014), para citar apenas alguns.

Apesar das referências, não encontrei nesses trabalhos algo que me aproximasse das reflexões jarawara sobre o assunto. Que as plantas apareçam como "filhas" dos humanos não é algo excepcional, pois essas relações foram anteriormente descritas dessa forma em sociedades ameríndias (ver Taylor 2000 e Descola 1986 e o exemplo acima, de Bonilla 2007; ver também os diversos trabalhos de Rival 2001, 2005, 2009 sobre as plantas entre os Huaorani, assim como o de Oliveira 2012 sobre plantas e modos de conhecimento wajãpi). O que me pareceu diferente é que na ação e na formulação jarawara e, sobretudo, na forma com que consegui vincular o dito e o mostrado havia algo que conectava plantas, mortos, cônjuges e filhos.

Mas se as inquietações que apresento se iniciaram com a narrativa de Wero, elas perduraram nebulosas por muito tempo, até que um dia, sentada na varanda da casa de minha amiga e "irmã" Narabi, rodeada por mulheres que falavam comigo sobre filhos e plantas, percebi que muito do que ocorria com o abono das plantas e com os mortos na camada superior 
estava lá na aldeia, sempre estivera na minha frente, na forma como as pessoas se relacionavam, cuidavam umas das outras, se casavam e criavam seus filhos. Essa visão me ocorreu em um primeiro momento em função do meu interesse pela "genealogia", pelas maneiras como os matrimônios se efetivavam e pelas formas vocativas pelas quais as pessoas se referiam umas às outras. Foi assim que cheguei às relações entre humanos e plantas, e é por isso que as reflexões que apresentarei aqui são, antes de mais nada, sobre o "parentesco" jarawara. Poderíamos dizer que o "parentesco" é meu "controle" (Wagner 1981) ao longo deste ensaio.

\section{Casar e "remendar"}

Se eu pensasse em um "trabalho" (Wagner 1981:18) que me definisse por muito tempo na aldeia Casa Nova, onde aprendi a maior parte do que descrevo aqui, ele teria sido a tentativa, um tanto frustrada, de mapear a genealogia. Visitei as casas repetidamente, fiz perguntas sobre os matrimônios, fui a todas as aldeias, desenhei e redesenhei árvores genealógicas que, como veremos, não poderiam ser nada mais do que intermináveis rascunhos. Mas se aquilo que chamamos de parentesco foi uma grande preocupação, esta foi se transformando ao longo dos anos: deixou para trás as categorias e as regras e se encaminhou em direção a algo que apontasse para como as pessoas viviam juntas e criavam uma "mutualidade do ser" ("mutuality of being") (Sahlins 2011). Este ensaio se construiu, de alguma maneira, em cima desta trajetória, partindo do "dravidianato", passando pelo roçado e divagando sobre crianças, almas (abono) de mortos e de plantas, todos participando em meu argumento como pontos de vista que não se totalizam (Lima 2002).

$\mathrm{O}$ "sistema terminológico" jarawara poderia ser visto como uma variante do dravidiano. O casamento "preferencial"/"prescritivo" é aquele que os Jarawara chamam de "bonito"/"certo" (amosákê). Para um homem, este casamento seria aquele com uma mulher "afim", da sua mesma geração, a quem ele chama de nakiri ("cunhada"), o que inclui, mas não se limita a, suas primas cruzadas bilaterais de primeiro grau (MBD ou FZD). ${ }^{5}$ Discorri sobre o "dravidianato jarawara" anteriormente (Maizza 2012), fazendo inclusive uma comparação com outros grupos Arawá, e não retomarei a discussão aqui, onde procurarei apontar, de forma etnográfica, apenas alguns de seus aspectos. ${ }^{6}$

Em uma tentativa de entender com quem se casaria um menino da aldeia, filho de mãe solteira e pai casado com outra pessoa, de cujo namoro considerado "errado" foi gerada a criança (como explicarei adiante), pedi para um amigo uma solução. Ele respondeu, sem hesitar, que o menino se 
casará com a filha do kokô ("sogro") dele, citando o nome de um dos irmãos da mãe do menino. A posição dos filhos dos irmãos dos pais, os "primos cruzados bilaterais", é a mais desejada para a realização de casamentos "bonitos"/"certos" (amosákê), sobretudo no discurso das pessoas que, ao falarem de suas próprias uniões, por exemplo, dão ênfase ao fato de terem se casado com uma prima cruzada, se este tiver sido o caso. Mas os matrimônios com as primas cruzadas bilaterais seriam tão amosákê, "bonitos" (ou tão "prescritivos"...) quanto casar com uma afim distante ou com uma "consanguínea" distante, transformada em "afim" (Maizza 2012:158). Isto nos lembra o que Viveiros de Castro (1996b) denominou de "dravidianato concêntrico", em que o autor sugere que nas sociedades amazônicas existiria uma afinização dos parentes distantes, sobretudo para fins matrimoniais.

Casar-se de forma "bonita" (amosákê) é uma preocupação de todos, sobretudo das mães com filhos em idade de se casar. Há um medo latente, eu diria, de as pessoas se casarem de forma "feia/errada" (amosákêre), ou seja, com alguém que elas chamariam de "irmão" (ayo, niso) ou de "irmã" (ati, asima), um parente paralelo da mesma geração em termos dravidianos. Ou então com pessoas de uma geração diferente da delas, a quem elas chamariam de "tio" (abisê)/“tia" (amisê), "sogro" (kokô)/"sogra" (asô), "filho"/"filha" (isini/ bese) ou "sobrinho"/"sobrinha" (bitimi) (ver Maizza 2012:116-117 para detalhes terminológicos).

Um casamento "errado" normalmente só é nomeado deste modo por outras pessoas, não pelos próprios cônjuges. Estes, no momento em que se casam, "remendam". Remendar é a expressão utilizada em português pelos Jarawara para traduzir o namosá neste contexto. Ela aponta para o fato de que os cônjuges transformam a maneira vocativa com que se referem ao esposo e também a alguns de seus parentes. No entanto, não vemos aqui, como nos Piaroa descritos por Overing (1975), entre outros, o uso de tecnonímios para "apagar" a afinidade, por exemplo, pelas mulheres se referindo aos cônjuges como "pai do meu filho". As pessoas parecem preferir transformar, namosá, em vez de "mascarar". Aquilo que os Jarawara chamam de "remendo" remete ao que ficou conhecido na literatura antropológica com o nome de "reclassificações". Para Lévi-Strauss (1949), as reclassificações seriam uma das características que definiriam os sistemas prescritivos, ou estruturas elementares, em que todos os casamentos, mesmo os que não se encaixariam na regra prescritiva, seriam descritos pelas pessoas como se se encaixassem. A divisão entre sistemas elementares e complexos foi problematizada ao longo dos anos (Viveiros de Castro 1996b; Taylor 1998), o que nos faz requestionar a própria ideia de prescrição matrimonial. Vejamos mais de perto um exemplo de "remendo", para pensar o que poderia ser o casamento em um "sistema prescritivo", como o dos Jarawara. 
Por volta de 1950, Kanabono ${ }^{7}$ — na época "chefe/cabeça" da aldeia conheceu um homem chamado Tatikuri, às beiras do lago Boritiana, onde morava. Os dois falavam a mesma língua, apesar de as entonações e o sotaque serem ligeiramente diferentes. Tatikuri falou que morava não muito longe de lá e se despediu. Alguns anos depois, diversas mulheres ligadas a Tatikuri apareceram na aldeia de Kanabono com seus filhos, explicando que os Apurinã haviam matado quase todos os seus parentes, do grupo Wayafi. Lembremos que esses encontros ocorreram em um dos momentos mais difíceis da história do Médio Purus, no final do segundo ciclo da borracha, quando as correrias, as doenças, e os conflitos entre grupos (muitos decorrentes dos ataques dos Brancos) exterminaram grande parte da população indígena na região. Entre as moças que sobreviveram ao ataque apurinã estavam Amoru e Janoa. Tanto a filha de Amoru como o filho de Janoa se casaram, em seguida, com filhos de Kanabono, como pode ser visto no diagrama abaixo. O outro filho de Amoru se casou com uma moça de outra aldeia, Iza, viúva e com filhos pequenos.

\section{Diagrama 1 - Ponto de vista de Ware}

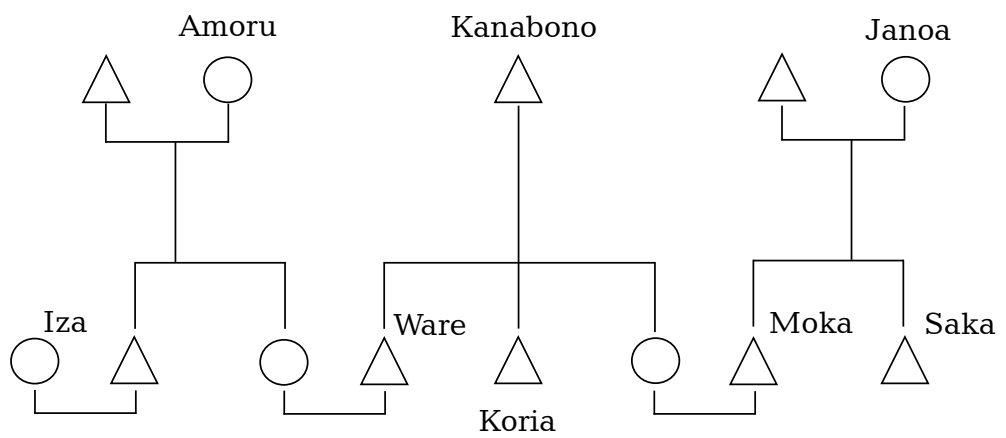

Nesse momento, Koria, filho de Kanabono, com quem conversei muito sobre o que relato aqui, chamava Iza de ati ("irmã"). Mas então, alguns anos mais tarde, o irmão (Saka) de seu cunhado Moka se casou com a filha de Iza. Saka, o noivo, passou a chamar Iza de "sogra" (asô), pois se casou com sua filha. Moka, irmão de Saka, fez o mesmo. A esposa de Moka passou então a chamar Iza de "tia" (amisê), visto que seu marido a estava chamando de "sogra" (asô). E então Koria, cunhado de Moka, também fez o mesmo que sua irmã, deixou de chamar Iza de ati ("irmã") e passou a chamá-la de "tia" (amisê). 


\section{Diagrama 2 - Ponto de vista de Saka}

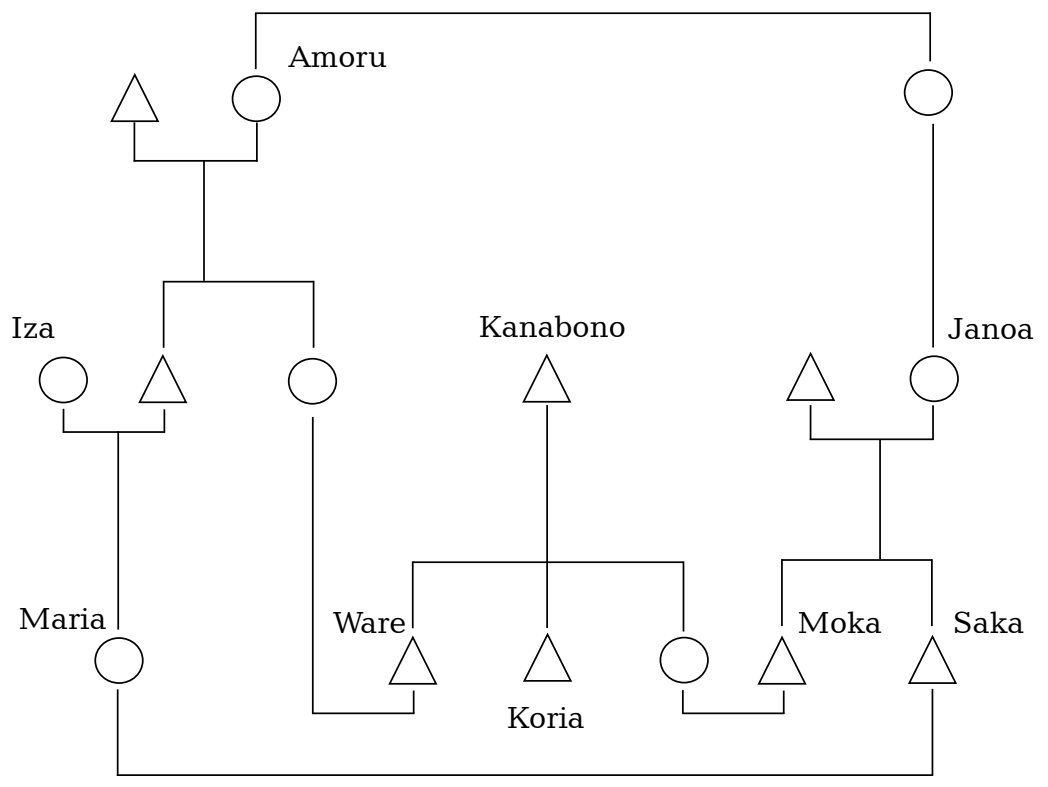

Poderíamos dizer que Saka, Moka e Koria "subiram" Iza uma geração, para que sua filha se tornasse da mesma geração que o homem com quem se casou. O que demorei a saber, no entanto, é que essa mudança tinha um detalhe importante: Amoru e Janoa, ambas do grupo Wayafi, tinham um vínculo entre si quando chegaram fugidas à aldeia Casa Nova: a mãe de Janoa, falecida, era "irmã" (asima) de Amoru. Por isso, quando Saka se casou com Maria, ele o fez com uma prima cruzada, como pode ser visto no diagrama 2. Aqui, o casamento da filha de Amoru com Ware é que seria "errado" (amosákêre). Ware, sua esposa, e seu cunhado (não casado) não fizeram as transformações e continuam a chamar Iza da forma como a chamavam antes.

Este exemplo reflete a dificuldade, ou mesmo a impossibilidade, de desenhar uma árvore genealógica única e "neutra" para algo que poderia ser visto como "o grupo Jarawara". Vemos que não existe uma única possibilidade, muito menos estática, e sim relações que se transformam e se atualizam: um desenho não pode ser mais do que um ponto de vista em um dado momento ou uma cristalização momentânea (Lima 2005).

As pessoas raramente voltam ao vínculo entre as mulheres wayafi para explicar as relações atuais; parece-me que, uma vez feita a mudança, não há mais a necessidade de justificá-la ou falar sobre ela. Por outro lado, a 
forma como os dois irmãos, Koria e Ware, se referem à Iza reflete algo sobre a proximidade entre as pessoas. Koria é solteiro e vizinho de casa de Moka. Este se casou com duas de suas irmãs, teve diversos filhos, alguns são criados por Koria e por suas outras irmãs solteiras que moram com ele. Moka, Koria e as mulheres, que são esposas de um e irmãs de outro, dividem espaços, trabalham e se alimentam juntos, formando um dos núcleos de convivência da aldeia. Como descreveu Joana Overing para os Piaroa (1993:206), os atos diários, como estar perto, cuidar, alimentar e trabalhar juntos, são aqueles que nos falam sobre a proximidade das pessoas, sobre os parentes. Isto explicaria porque Koria e suas irmãs transformaram Iza em amisê. Koria se lembra do dia em que isso ocorreu, dizendo que primeiro seu coração parou e depois teve muitas "dores de cabeça" (tati komá), o que apontaria para um estado corporal do namosá e nos lembra as descrições de Coelho de Souza $(2004: 43 ; 45)$ sobre os Timbira, nas quais a autora diz que o parentesco é um processo medido pelo sucesso de fabricação de corpos assemelhados. Seria quase como se, ao transformar a forma vocativa como se referia à Iza, Koria estivesse transformando seu corpo como em uma mudança de perspectiva (Viveiros de Castro 1996).

Já Ware mora em outra parte da aldeia, com seu cunhado João, irmão da sua esposa, seu vizinho de casa. Ware, seus filhos, genros, netos e cunhado (João) formam um núcleo separado de pessoas que se relacionam e convivem no dia a dia. Ware e João dizem que o Saka "está perdido", casou errado, de forma amosákêre. Os filhos de Ware se casaram levando em consideração as posições que aparecem no primeiro diagrama. Os filhos de Saka, as que aparecem no segundo. Os filhos de Moka, ainda solteiros, oscilam entre as duas possibilidades. Como sugeriu Viveiros de Castro, a posição dos primos cruzados estaria mais para um "valor zero", o importante seria a "presença de uma oposição não neutralizável em G+1: a oposição entre consanguíneos e afins resultante da troca simétrica que teve lugar na geração imediatamente anterior à de Ego [...]" (1996b:83, grifos do autor).

Strathern, ao falar de atividades políticas e rituais na Melanésia, sugere que "apenas efeitos validam procedimentos" (only effects validates procedures) (1988:186): é pelo efeito ritual que as pessoas de Hagen saberiam se ele foi feito da maneira como deveria ter sido. Poderíamos seguir essa diretriz para pensarmos os casamentos jarawara. É como se devêssemos esperar os casamentos da geração seguinte (G-1) para saber se o "remendo" de um casamento surtiu o efeito desejado - transformar um tipo de relação em outra. Em um grupo de apenas 200 pessoas que se casam entre si há anos, todos estão vinculados de inúmeras maneiras. As transformações poderiam ser vistas só como possibilidades que já estavam em algum lugar no meio 
do emaranhado das ligações que unem as pessoas. Mas não é exatamente a veracidade dos vínculos que parece dizer algo sobre o que acontece. O exemplo do "remendo" de Koria devido ao casamento de Saka aponta para essa questão: não é porque Janoa era amisê de Amoru (ou porque era "verdade" que a filha de Iza era prima cruzada de Saka) que Koria "remendou" e passou a chamar Iza de amisê, mas sim porque Moka, o irmão de Saka, é seu cunhado, com quem suas irmãs são casadas, pai de seus sobrinhos mais próximos, pessoas com quem convive, divide trabalho, se alimenta, caça, pesca e cultiva.

As mudanças, os "remendos", nos dizem pouco sobre que tipo de parentes as pessoas são, mas mostram sobre que tipo de parentes elas querem ser... (Coelho de Souza 2004). Os casamentos das gerações seguintes elucidariam algo sobre o efeito dessas transformações medindo o sucesso das renovações, dos namosá. Se pudéssemos falar do "parentesco jarawara", talvez ele estivesse mais próximo dessas intenções, desses movimentos de embelezamento, dessas aberturas para o namosá e seus efeitos tardios do que das "prescrições matrimoniais" e suas "reclassificações".

\section{Pais de criação}

Se o casamento amosákê é uma questão importante para as pessoas, outra, talvez tão importante quanto ela, seja a criação de filhos. Nunca conheci um casal que não criasse, ou tivesse criado, pelo menos um filho junto. Alguns casais têm muitos filhos, e nesse caso é o pai que trabalha para fazer a criança na barriga da mãe. Em seguida, quando a criança nasce, tanto o pai quanto a mãe trabalham juntos para criá-la. Os casais que se encontram diante da impossibilidade de conceber, por qualquer motivo que seja, criam filhos de outras pessoas.

Essa "criação de criança de outra pessoa" corresponderia ao nayaná na língua jarawara, na qual se diz, por exemplo, Manira owa nanayaná, "Manira me criou", normalmente em contraste com o termo "de verdade", yokaná: Narabi okomi yokaná, "Narabi é minha mãe de verdade". As crianças chamam seus pais de criação de "pai" (abi) e "mãe" (ami) e, quando muito pequenas, não sabem que estão sendo criadas por pessoas que não são seus pais, mas ao longo do tempo entendem. Quando já estão "grandinhas" e começam a chamar as pessoas em seu entorno por termos vocativos, elas passam pelas relações de seus pais yokaná, e não pelas de seus pais de criação. O nayaná é uma prática recorrente e parece ser outra forma de falar sobre a proximidade entre as pessoas. Na página ao lado, temos um gráfico que resume ${ }^{8}$ os 31 casos de criação que conheço. ${ }^{9}$ 


\section{Gráfico 1 - Distribuição das crianças segundo a classificação dos pais de criação}

Pais de criação

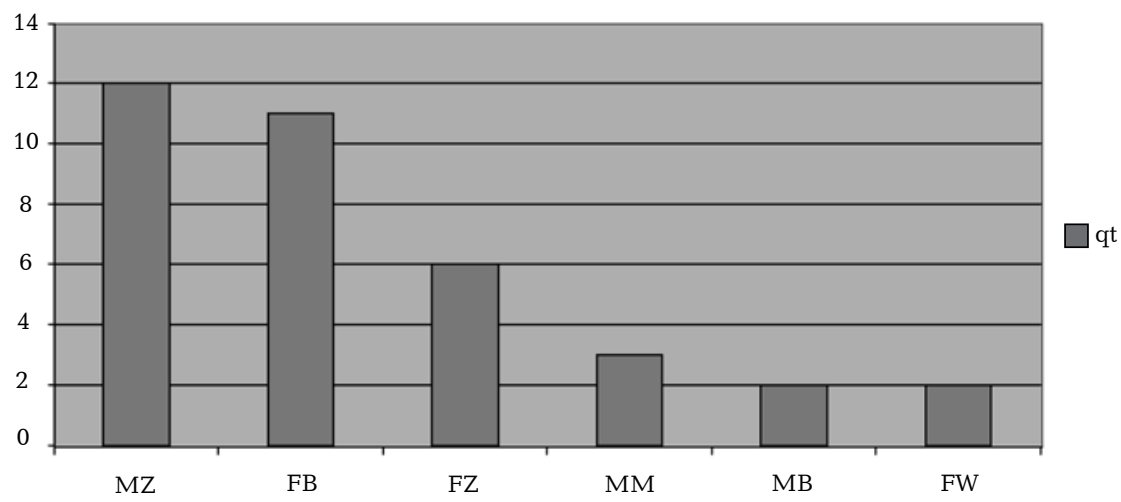

Vemos que, quando as pessoas falam de pais de criação, elas fazem referência sobretudo ao fato de ser um dos irmãos dos pais a cuidar da criança, em vez de seus pais "de verdade" (yokaná), de preferência um irmão do mesmo sexo, ${ }^{10}$ isto é, um "tio" ou uma "tia" paralelo(a) (MZ, amisê ou FB, abisê). Mais de $60 \%$ das crianças estão sendo criadas dentro deste tipo de relação. A outra possibilidade, menos praticada do que a primeira, mas também importante ( $20 \%$ dos casos, aproximadamente), é a criança estar sob os cuidados de um dos irmãos de seus pais, de sexo oposto ao deles um "tio" ou uma "tia" cruzado(a) (FZ, asô e MB, kokô). Os avós maternos (MM) podem igualmente assumir a posição de pais de criação, assim como os novos esposos dos pais verdadeiros (FW), se as crianças do cônjuge forem pequenas no momento da união.

Se quem cria é um irmão do mesmo sexo dos pais, a criança não precisará mudar seus vínculos; em termos "estruturais" (do "dravidiano"), é como se seus pais a estivessem criando. Como segunda possibilidade, os irmãos de sexo oposto ao dos pais criam a criança. Mas esta não muda seus vínculos: ela continuará a passar pelas ligações de seus pais "verdadeiros" (yokaná). Esses pais de criação estão, assim, em posição de se tornarem sogros da criança de que cuidam, caso eles mesmos tenham um filho que se case com ela. Estamos aqui diante de algo que poderia ser questionado: é pai ou é sogro? É mãe ou é sogra? Imagino que a resposta seria algo na mesma linha do que vimos através da ideia dos "remendos" (namosá) dos casamentos: "se criar, é pai, se casar com a filha, é sogro", como se apenas 
a relação presente contasse, e também como se o efeito de uma criação pudesse ser um casamento (com os filhos de quem criou a pessoa).

Quando duas irmãs são casadas com um mesmo homem e uma delas não pode ter filhos, é muito comum que esta crie os filhos de sua irmã com o marido de ambas. Como os casamentos acontecem em geral entre pessoas que moram na mesma aldeia (existiria uma "endogamia de aldeia", ver Maizza 2012), uma criança criada por seus "tios cruzados" morará, na maioria dos casos, na mesma aldeia que seus pais. Quando há criação pelos avós maternos, normalmente as mulheres são mães solteiras e moram na casa de seus pais. Assim, a maioria das crianças é criada por pessoas que moram na mesma aldeia que seus pais, e às vezes na mesma casa. A proximidade entre os pais de criação e os pais yokaná de uma criança seria um fator inerente ao nayaná. Por isso, o nayaná, ou "a criação (de criança)", não equivaleria ao nosso conceito de adoção. Se por adoção pensamos em crianças que em um primeiro momento foram abandonadas pelos pais para, em seguida, serem criadas por estranhos com quem não têm inicialmente vínculos, aqui a criação passaria sobretudo pela proximidade, tanto dos vínculos como do lugar onde moram os pais de "verdade" e de criação.

Tudo leva a acreditar que o nayaná não corresponde também à domesticação ou à criação de animais domésticos, mas há um diálogo entre estas duas formas de criar. A grande parte dos bichos de estimação chega à aldeia com os jovens, que caçam e matam as mães e trazem os filhotes para serem criados por eles ou alguém próximo, normalmente sua mãe, esposa, ou irmã. As pessoas não dão nome a seus animais e os chamam pelo nome da espécie, por exemplo, wafa (macaco barrigudo), o que parece demonstrar uma vontade de explicitar a distância da relação. Elas os alimentam, lavam e, na maior parte do tempo, os deixam presos, amarrados ou em uma casinha feita para eles. Por isso acredito que um animal doméstico é Outro, filho de pais desconhecidos, e se aproxima da adoção tal como definida em nossa sociedade. Aproximar-se-ia igualmente daquilo que os Jarawara chamam de "roubo" (boti), que discutirei no fim deste ensaio.

O nayaná e a expressão dnayá nahô ("estou criando", "minha criação") podem ser utilizadas também para animais, mas muitas vezes o nawatá é preferível para falar de criação de animais. Nawatá seria algo como criar, mas que remeteria também ao segurar e amarrar, algo como "criar segurando". Porém, voltando um dia do roçado com certas pessoas, um homem que estava mudando temporariamente de aldeia vinha no sentido oposto ao nosso e, atrás dele, seu queixada, que o seguia sem estar amarrado. Minha acompanhante me explicou que o porco só seguia aquele homem, pois fora criado por ele, dando a entender que ele só obedeceria a seu "dono" e a 
ninguém mais, e só o fazia porque gostava dele - o que nos faz pensar na domesticação como uma mistura de "coerção" e "sedução" (Taylor 2000:314).

Entre os Paumari, Bonilla fala de filhos "adotivos", que seriam empregados de seus pais (Bonilla 2005:48), a "adoção" sendo um meio de pacificação do Outro, como se observa em um relato sobre uma criança que foi criada pelos inimigos Joima, e anos depois salva seus parentes paumari da agressão deles (:53-54). A autora igualmente vincula à "adoção" o tempo passado pelos jovens paumari com seus patrões em suas adolescências (:45). Neste último caso, Bonilla (2007:338) fala de crianças "adotivas" como sinônimo de "afilhados". Entre os Paumari, parece que a criação se aproximaria de uma mistura de nossa ideia de adoção e apadrinhamento e lembraria a domesticação de animais, tal como descrita acima. A "adoção" paumari seria, assim, uma forma de se colocar em posição de presa para "controlar" a relação com um predador, como várias outras formas discutidas por Bonilla (2007). Entre os Jarawara, ser pai/mãe de criação, como vimos, significa criar o filho de uma pessoa muito próxima e conhecida, em 80\% dos casos, o(a) filho(a) de um irmão ou uma irmã. O nayaná nos fala, assim, sobre relações de proximidade, de convivência, de cuidado mais do que sobre relações de predação. No entanto, a possibilidade de ser criado por outro tipo de gente, como relata Bonilla, não fugiria completamente à lógica das criações jarawara, o que retomarei no final do ensaio.

Nayaná, "criar", remete a um conjunto de ações que incluem o dar banho, alimentar, vestir, pôr na rede para dormir, educar, comprar roupa na cidade. A pessoa que cria ensina suas atividades a seus filhos do mesmo gênero: as meninas aprendem com suas mães a cozinhar, a lavar roupa, a fazer artefatos; enquanto os meninos aprendem com seus pais a pescar, a caçar, a fabricar flechas, a construir casas e a abrir roçados. O aprendizado se dá pela observação e participação; os pais levam seus filhos pequenos às suas tarefas diárias para ensinar-lhes, e estes aprendem gradualmente. Em contrapartida, a criança ajuda seus pais ao adquirir o conhecimento. Foi-me dito que o processo de criar dura somente a infância e que, com aproximadamente 13 anos, a pessoa estaria criada, o que não significa que o carinho e a atenção tenham terminado, mas apenas que, de alguma forma, ela precisa de menos cuidados de seus pais.

O nayaná não rima com abandono, mas sim com "cuidado" (narifá) e "sedução" (nofá). Não seria a mãe que renunciaria a seu filho esperando que alguém cuidasse dele em seu lugar, mas sim o filho que se deixaria seduzir por outra pessoa, que comprovasse, por meio de ações, que cuidaria bem dele. A criança escolhe os "pais de criação" por um processo de aproximação e costume. Quando a criança é ainda pequena, com poucos meses, os "pais 
de criação" se aproximam e fazem tudo para ela gostar deles: compram leite, chamam para dormir na rede junto, passam bastante tempo por perto, olhando, ficam atentos a qualquer choro. No final, a criança não quer mais ficar com seus pais de verdade (yokaná) e escolhe seus novos pais, em um movimento que demonstra que ela começa a gostar (nofá) mais dos pais de criação do que dos verdadeiros. A mãe, ami yokaná, muitas vezes faz tudo para que esta sedução alhures não ocorra, e sempre negará um pedido para "dar" seu filho a outra mãe, mas em certas ocasiões já é tarde demais. Diversas crianças que foram seduzidas por "pais de criação" têm irmãos quase da mesma idade. Normalmente, as crianças de criação recebem uma dupla atenção, pois seus pais yokaná ainda se preocupam com elas, mesmo que não cuidem dela fisicamente no dia a dia. Na velhice dos pais, os filhos de criação, como os outros filhos, cuidam daqueles que os criaram.

De alguma maneira, o "criar" (nayaná) nos fala muito sobre o que seria o "cuidar" (narifá), é quase como se um significasse o outro. Quem está criando está também cuidando. E quem está cuidando está também criando. E quem está criando e cuidando está também olhando. O olhar, kakatomá, é outra maneira de falar de cuidado, de criação, de proximidade, de atenção. Todas essas ideias se entrelaçam no momento em que percebemos as conexões entre pais e filhos, sejam eles de "verdade" ou de "criação", mas também entre cônjuges, entre irmãos e cunhados que vivem juntos, entre genro e sogro... É como se, na convivência cotidiana, as pessoas tivessem que se afastar o máximo possível do hamaká ("estar bravo, com raiva") e se aproximar cada vez mais do nofá, "gostar", "estar sendo gostado", "seduzir".

Esse movimento em direção ao gostar ocorreria no coração/fígado/ pensamento (ati boti): as pessoas precisam se vigiar para não ter "raiva" das outras com quem convivem ou com quem querem conviver, a "raiva" remetendo à ideia de não parente. Por exemplo, uma mãe, cuja filha se casou com um homem que não é jarawara e foi morar em outra localidade sem seu consentimento, ficou muito "triste/brava" (yawa). Quem me contou isso foram suas irmãs. Essa mãe, ao falar do casamento, tinha um ar ressentido, ao mesmo tempo em que afirmava não estar com raiva. Era como se, por ter raiva, pudesse perder sua filha para sempre. Alguns anos depois, retornei à aldeia, e a mãe, o pai, os irmãos e as irmãs da menina haviam feito um grande esforço para "amar"/" aceitar"/"gostar" (nofá) do marido estrangeiro, aproximando-se e procurando passar mais tempo próximo a ele através de visitas prolongadas ao casal.

Como mostra Garcia (2010), para os Awá-Guajá, a ideia de criação envolve um conjunto amplo de seres, sugerindo uma multiplicidade de relações em diferentes esferas do socius. Algo nessas linhas poderia ser 
dito sobre a "criação" jarawara: o nayaná é formado e se forma com outras relações, entre as quais o narifá ("cuidar"/"educar"), mas também o nofá ("gostar"/"seduzir"). Assim como discuti sobre o namosá em forma de "remendo" dos casamentos, no início deste ensaio, esses conceitos não se encontrariam dados, mas seriam tipos de relações em que a intenção seria primordial e cujos efeitos são medidos ao longo do tempo. Eles possivelmente teriam um "idioma simbólico corporal" (Seeger, DaMatta \& Viveiros de Castro 1979), mas também, e sobretudo, nos diriam sobre as ações baseadas na vontade, no gostar, no seduzir (nofá). Se o parentesco, como afirmou Viveiros de Castro (2002), for um processo infinito de retirada de afinidade, entre os Jarawara essa "despotencialização da afinidade" remeteria justamente às intenções de embelezar, de cuidar, de criar, de seduzir. Intenções sempre à espera de um efeito (Strathern 1988), efeito no outro.

\section{As crianças-planta}

Se as reflexões até agora nos fazem pensar o parentesco como domínio exclusivamente humano e separado de outras áreas da vida, sigo os passos que me foram mostrados na varanda da casa de Narabi na direção das crianças-planta.

Para os Jarawara, as almas das plantas saem de seus corpos e vivem socialmente em diferentes lugares do cosmos, sobretudo no nemê. A palavra "alma" é a que utilizarei para traduzir o termo abono, assim como fazem os Jarawara. Como veremos, o que eles chamam de alma não tem exatamente o mesmo sentido com que nós dizemos esta palavra. Alma, para eles, estaria mais próxima daquilo que ficou conhecido na literatura antropológica como sujeito-potencial (Viveiros de Castro 1996; Lima 1996). As almas de plantas seriam algo como sujeitos-potenciais-planta. Ocasionalmente, vou chamá-las de gente-planta, remetendo a esta mesma ideia. Como sugeriu Bonilla (2007) em sua tradução de "alma-corpo" para um termo similar em paumari (aboni), o abono nos parece falar, de alguma maneira, também de diferentes corporalidades.

Os abono das plantas que as pessoas cultivam em seus roçados moram no nemê, em lindas aldeias, muito parecidas com a cidade de Lábrea, no Amazonas, que os Jarawara visitam a cada início de mês: com motos, carros, prédios, luzes, casas de tijolos ${ }^{11}$ e muita gente. As almas das plantas cultivadas são chamadas de yamákorona abono ("alma de coisa-plantada"), mas podem também ser chamadas de yamátá abono ("alma de comida"), visto que as pessoas parecem cultivar sobretudo aquilo que gostam de comer. 
Foi-me dado a entender que só se cultivam as plantas que crescem rápido, pois não faria sentido plantar algo que não se comeria, ou se usaria, ou que não se visse crescer. Este dado, sem dúvida, lembra o argumento de Rival (2005), segundo o qual entre os Huaorani é a forma de crescimento, devagar ou rápido, que distinguiria as espécies.

Tudo leva a acreditar que exista uma diferença importante entre as espécies cultivadas pelos Jarawara e as não cultivadas ou cultivadas por outros tipos de seres. As espécies não cultivadas seriam sobretudo aquelas que encontramos na região da várzea, como as palmeiras boriti, boritiana e joari. Foi-me dito que quem planta e cuida dessas almas-planta são os yamá e os yamá maka, sujeitos-potenciais que moram nos fundos de rios e lagos e que raptam a alma dos humanos que, sem saber, se encontram sozinhos em seus territórios. Já as árvores da floresta são normalmente chamadas de "pau velho" (awa boté) e vinculadas às "almas velhas predadoras" (inamati boté), comedoras de gente e moradoras em buracos no solo.

As plantas e também seus abono são divididos de acordo com suas "forças". As forças das espécies estariam diretamente relacionadas aos seus corpos, às suas características físicas e fisiológicas: as dimensões dos troncos, alturas, propriedades medicinais e terapêuticas. Desta maneira, as árvores "jovens" (yatí) seriam as mais "fortes" (kitá), assim como as plantas que possuem veneno ou uma substância química ativa ou passiva de ser ativada: o tingui (kona), o cipó-do-mato (ihá, bikafa, utilizado para caça), o tabaco (sina, usado para fabricação do rapé), a pupunha (yawitá) e a mandioca brava (fowa), que não podem ser consumidas cruas. Já as plantas comestíveis e suas almas (yamátá abono) são geralmente nomeadas de "fracas" (kitárê): a cana (kana) e o abacaxi (sami), porque têm açúcar, a macaxeira (fowakabe) e o cará (bihá), porque podem ser consumidos sem grandes manipulações, e diversas outras, como o abacate, a manga e o açaí, que não chamam a atenção em suas atividades guerreiras. Isto porque o mundo da gente-planta é, antes de mais nada, um mundo de guerra, de inimigos, de disputas constantes entre os abono das plantas cultivadas contra os abono das plantas não cultivadas ou cultivadas por Outros: brigas das yamákorona abono contra os awa abono.

O processo que separa as almas das plantas de seus corpos se assemelharia a um nascimento (ou à morte): uma pessoa semeia em seu jardim; algum tempo depois a planta sai do solo e começa a crescer. Quando ela atinge certa altura, estando ainda pequena, baixa, sua alma sai de seu corpo e fica ao lado deste, chorando. Os xamãs dizem que a alma da planta tem a aparência de um bebê humano e é filha da planta da qual saiu. A alma da pupunha (yawitá abono) é filha da pupunha, por exemplo. Esse processo pode 
ser entendido, através de uma visão externa, de três maneiras. A primeira é que a alma seria um "clone" do corpo, e haveria uma relação de "consanguinidade plena" (Taylor 2000:320) entre a alma e o corpo da planta, sendo a alma a própria planta. ${ }^{12}$ Uma segunda forma de interpretação se apoia no conceito de "dono" e "mestre" (Fausto 2008) e supõe que todas as bananeiras, por exemplo, estejam ligadas à uma mesma "matriz reprodutora", um tipo de "dona das plantas", que seria a mãe/mestra de todas as plantas da mesma espécie. Ambas as reflexões apontam para uma identificação e uma semelhança entre o corpo e a alma das plantas. No entanto, acredito não se tratar nem de clones, nem de donos, mas sim de um terceiro conceito, o conceito de duplos (Lima 1996), o mais apropriado aqui.

Essas crianças que choram ao sair do corpo-planta seriam, além de filhos das plantas, filhos da pessoa que semeia: "okatao yokaná é meu filho de verdade, me chama de okobi (meu papai)", me disse um amigo. Deixemos este primeiro grupo de relações em suspenso e continuemos até o nemê. Após sair de seu corpo-planta, a criança-planta chora e é então levada "lá para cima" por almas de plantas que já moram no nemê e descem apenas para buscá-la. Ela é então criada por um casal de gente-planta (não necessariamente da mesma espécie que ela), que a nomeia. Ao crescer, chamará de pais os componentes do casal.

Quando morrerem, as pessoas também irão para o nemê. De fato, só uma das três ou quatro almas que saem do corpo do defunto irá "lá para cima" aqui falarei apenas sobre ela. Assim como as plantas, após o enterro, a alma do morto sai da cova e fica esperando para ser levada. A grande diferença é que, apesar de ter a aparência humana, ela não seria uma criança. Quem desceria para buscá-la seriam seus próprios filhos-planta: almas de plantas que a pessoa cultivou em vida e que foram levadas para o nemê quando pequenas. Ao chegar, a alma descansa, rejuvenesce (namosá), vai para outra aldeia para uma festa, muito parecida com as festas de iniciação das meninas na Terra (mariná/ayaka). Em seguida, ela se casa. Este seria o destino de grande parte das pessoas, a não ser daquelas que falecem crianças, que serão criadas no nemê por um casal de gente-planta. Assim, há duas possibilidades para as almas (os abono das pessoas e das plantas) que se dirigem "lá para cima": serem criadas ou se casarem. Voltarei a seguir a estas relações; antes, uma pequena palavra sobre os xamãs (inawá).

O inawá, por meio da inalação de rapé, consegue se comunicar com as almas de plantas do nemê. É ele quem as avisa para virem buscar tanto as crianças-planta como as almas dos mortos. O xamã tem seus próprios filhos-planta, almas de plantas que cultiva, que vêm buscá-lo periodicamente e o levam ao nemê, onde ele encontra e conhece grande parte dos 
filhos-planta dos outros moradores da aldeia. Inversamente, essas almas descem a Terra quando chamadas pelo xamã; ao chegarem, dizem seus nomes e suas "origens": falam algo como "eu sou a alma da pupunha que a Hinabori plantou, me chamo Nanafina". Ou então: "você me conhece, você plantou pupunha, eu sou filho da pupunha, eu sou seu filho". O inawá chama os abono regularmente para conversar, fazendo com que as pessoas descubram novos nomes dos quais se apropriam ao longo da vida. As pessoas da aldeia Casa Nova se chamam, por exemplo, Kanabono (alma de cana), Efewarisari, Dyimanarabi, Nanafina (almas de pupunha), Makeni (alma de manga), Dyimayairiri (alma de tingui), Dyimamani (alma de morto); são nomes que as almas das plantas, ou dos mortos rejuvenescidos, receberam no nemê, nomes que poderiam nos fazer pensar a existência humana como um devir-planta (Viveiros de Castro 2007).

O xamã seria o único capaz de ver as almas de plantas e mortos sob a aparência humana sem que isto traga problemas (Viveiros de Castro 1996). O rapto de alma é o maior perigo do mundo jarawara (Maizza 2012) e um assunto permanentemente presente na vida das pessoas, em suas idas ao porto, à floresta, ao roçado. Se elas se encontrarem sozinhas fora da aldeia, podem ter suas almas raptadas por seres chamados inamati ou yamá, seus corpos adoecem e elas morrem se não forem curadas por um xamã. Quando algo desta natureza acontece, o xamã percebe que a pessoa não está bem e sente o cheiro dos malfeitores; ele sabe que o corpo da pessoa está na sua frente, mas que sua alma está amarrada em algum lugar — a alma e o corpo se separariam nesses momentos, que são, por isso mesmo, extremamente perigosos (Vilaça 2005). O xamã então chama as almas das plantas de seus roçados, seus filhos, pois serão eles que irão procurar a alma presa, lutar contra os sequestradores e trazê-la de volta. Mas não qualquer filho-planta, apenas aqueles que possuem muita "força" (kitá): as almas do tingui (kona abono), da pupunha (yawitá abono), do tabaco (sina), por exemplo. Por isto, um bom xamã seria antes de mais nada um bom cultivador — diferente de muitos povos Tupi, para os quais ele seria sobretudo um bom caçador (ver, por exemplo, os Awa-Guajá descritos por Garcia 2010). O bom êxito das ações do inawá depende de seus filhos-planta e de seus roçados.

\section{Fatará}

O fatará, o roçado, é um espaço que mulheres, homens, casais, irmãos frequentam juntos - diferente de muitos povos amazônicos, como os Achuar, por exemplo, para os quais o roçado é um espaço tipicamente feminino 
(Descola 1986:266). As pessoas visitam regularmente as plantações para roçar, verificar o crescimento das sementes, colher, observar, cuidar de suas plantas e conversar com elas. É preciso falar às plantas, explicando-lhes que devem dar frutos grandes. Os abono das plantas escutam e respondem, fornecendo os frutos. Paralelamente, e talvez até mais importante do que falar com as plantas, é olhá-las. Sobretudo quando elas ainda estão pequenas, acabaram de sair do solo, as pessoas vão frequentemente ao roçado para "espiar" (kakatomá).

Como vimos, o olhar vai par a par com o cuidar, com o criar, com o embelezar. Quando vão ao roçado "olhar", as pessoas tiram plantas daninhas de perto daquelas que estão crescendo e limpam o terreiro. As plantas não gostam de mato fechado; se o terreiro não estiver devidamente limpo, elas não crescerão. Por isso, o "cuidar" (narifá) das plantas é também traduzido como "ajudar a crescer", "cuidar para não morrer". E o cuidar do roçado se expressa pelo namosá: fatará onamosá: "eu limpo, cuido, arrumo, deixo bonito, tiro plantas daninhas do meu roçado", ou seja, "eu o deixo bom/ bonito/adequado para as plantas crescerem". O cuidado com as plantas e com o roçado remete ao que foi descrito para o cuidado com as crianças e com os parentes em geral. Ele seria um movimento de intenção, cujos efeitos são medidos a posteriori. Uma pupunha, por exemplo, só nascerá se tiver sido plantada da forma correta e se a pessoa que a plantou se preocupou com ela e fez o que deveria ter feito: "cuidou/limpou/olhou" (narifá). Pelas plantas que nascem e sobrevivem é que vemos se a pessoa cuida de forma "certa"/"bonita" de seu cultivo.

Como já explicado, quando a planta cresce um pouco, sua alma sai e é levada para o nemê por uma outra alma de planta, que dela pode cuidar ou entregá-la a um casal (de alma de plantas). As almas de planta do nemê se tornarão pais de criação das almas de plantas dos roçados. Os pais verdadeiros destas crianças-planta são os Jarawara e a planta matriz. Elas serão criadas no nemê e, quando pequenas, não saberão que aqueles são seus pais de criação. Quando ficarem "grandinhas", serão informadas sobre quem são seus pais e mães verdadeiros (yokaná), no caso, pessoas que moram na mesma aldeia que o xamã, a quem elas visitarão regularmente e receberão em suas visitas celestes. Na Terra, elas pedirão notícias de seus familiares ao xamã, querendo saber se eles estão bem e com saúde.

Quem normalmente cria o filho-planta das pessoas são os irmãos-planta, ou seja, os filhos-planta do pai humano da pessoa. Assim, os roçados dos homens com muitos filhos devem ser grandes e ter muitas plantas, pois são as almas delas que irão buscar as almas das plantas de seus filhos humanos. Os filhos-planta das pessoas serão criados no nemê pelos irmãos de mesmo 
sexo que seus pais, seus "tios paralelos" (MZ, amisê ou FB, abisê), ou então pelos irmãos de sexo oposto ao de seus pais, seus "tios cruzados" (MB, kokô ou FZ, asô), gente-planta. Estes tios podem também ser almas de humanos que morreram, filhos do xamã ou filhos de outras pessoas da aldeia. Estas duas possibilidades podem ser expressas de forma inversa pelas pessoas, que não sabem bem ao certo o que acontece no nemê: "criou meu filho, é meu irmão". Finalmente, há a possibilidade de a criança-planta ser criada por seu irmão-planta mais velho (ayo, homem ou ati, mulher), ou seja, pela alma de outra planta do roçado da pessoa que o cultivou. No nemê, o nayaná ("criar") abarcaria também cuidado, atenção, educação, carinho, sedução. Na Terra, as pessoas continuam cuidando de seus roçados, olham, conversam com as plantas. Talvez pudéssemos pensar o cuidado com os roçados como uma forma de cuidado com os filhos-planta, que estão sendo criados por outros pais no nemê - da mesma forma que os pais yokaná se preocupam e cuidam de seus filhos que estão sendo criados por outras pessoas, normalmente seus irmãos.

\section{Nemêyá}

Vinda nas costas de seu filho-planta nemêyá ("lá em cima"), a alma da pessoa morta é levada para a casa de um "conhecido", instala-se temporariamente, rejuvenesce (namosá), passa por um ritual, recebe outro nome e depois se casa. O acolhimento se daria na casa de seu pai (abi), ou na casa de um "sogro classificatório" (kokô), ou na casa de uma "irmã" (ati, asima)/ casa de um "cunhado" (wabori). Nestas três opções a diferença entre mortos e almas de plantas não é identificável: não é importante saber se o pai, o sogro, a irmã ou o cunhado são pessoas que faleceram ou se são almas das plantas do roçado. O que se acentua no discurso são as uniões matrimoniais.

Se a alma for para a casa de seus pais, ela se casará provavelmente com um de seus primos cruzados bilaterais. No entanto, a opção que mais se enfatiza no discurso masculino é a que complementa a primeira: ao chegar ao nemê, ela irá para a casa de um "cunhado" de seu pai, seu sogro classificatório (kokô), e se casará com a filha dele (gente-planta ou morto). Finalmente, a última possibilidade, também bastante apreciada, é ir para a casa de uma irmã, mais velha ou mais nova (ati ou asima), que é a mesma residência do cunhado (wabori), e casar-se com a irmã do cunhado. O realce parece estar no tipo de parente (pai/sogro/irmã) que a acolheria, e não na sua condição terrestre (humano ou planta).

O importante é que o recém-chegado se case de maneira amosákê ("bonita") com um primo cruzado, com o filho de um cunhado do pai (ou 
de uma cunhada da mãe), ou com um afim - assim como no "dravidianato concêntrico" (Viveiros de Castro 1996b) discutido anteriormente. As classificações no nemê se baseiam nas classificações na Terra. A filha-planta de X poderá se casar com o filho-planta do cunhado de $\mathrm{X}$, seja ele morador da aldeia ou do nemê. Mas ela não poderá se casar com o filho-planta do irmão de X. Como no nemê, a grande maioria dos seres é gente-planta; os mortos, uma vez rejuvenescidos, se casam sobretudo com elas, o que é bastante apreciado, pois elas são jovens e bonitas, fáceis de casar. Se no nemê todo mundo é lindo e o casamento não é um problema, pouco se sabe sobre a procriação e a atividade sexual, jamais mencionadas. Ao relatar o que acontece "lá em cima", as pessoas falam geralmente de seus filhos-planta, ou de seus filhos que morreram quando crianças e estão sendo criados por seus irmãos (plantas ou mortos).

Tudo leva a acreditar que as pessoas no nemê se casariam mas não teriam filhos, o que lembra a vida póstuma dos Krahô (Carneiro da Cunha 1978:128) e dos Piaroa (Overing 1993:204), por exemplo, mas que se diferencia destes pelo fato de haver aliança, lembrando-nos então dos Araweté (Viveiros de Castro, 2002b:271, 273). Quanto aos grupos Arawá, os Paumari optariam em morar com seus parentes ou navegar indefinidamente a serviço do "Patrão Chuva" (Bahi kapamoarihi) (Bonilla 2007:375). No primeiro caso, eles estariam "liberados da afinidade" (:374) e, no segundo, morariam com o "predador por excelência" (:377), mas em posição de afilhado ou empregado. Esta segunda posição parece mostrar a possibilidade que há entre os Jarawara: a de o mundo póstumo ser uma posição privilegiada para a reflexão sobre o que acontece na vida cotidiana das pessoas, sobre aquilo que poderiam ser suas grandes preocupações. ${ }^{13}$

As fases de crescimento de uma pessoa estão divididas aproximadamente da seguinte forma: criança recém-nascida (inamatevê biti/bite), criança (inamatevê), mocinhos (yetene biti/atoná bite), moços (yetene/atoná). As meninas passam então pelo ritual de iniciação e entram, como os meninos em torno dos 13 anos, na fase adolescente (hohowa ka/ kê), uma fase sexualmente ativa, de namoro e de aprendizagem sexual. A fase adulta (howaraka/ kê) é a do casamento e dos filhos. Finalmente, há a velhice (boté).

Se retomarmos as ligações entre humanos, plantas e mortos, veremos que as almas das plantas são criadas no nemê desde bebês; os mortos casam-se no nemê após rejuvenescerem e passarem pelo ritual de iniciação; as crianças que morrem pequenas têm pais de criação. ${ }^{14}$ Seria então possível relacionar a fase de vida terrestre das pessoas com o que ocorre no nemê ou, em outras palavras, relacionar os ciclos de vida da alma com os ciclos de vida de seus corpos. ${ }^{15}$ Uma planta ou uma pessoa pequena teria uma 
alma criança que seria facilmente criada por um casal, pois estaria na fase em que pode ser cuidada. Uma pessoa que morresse ainda jovem ou adulta já estaria criada e teria que se casar para se inserir no nemê. Uma planta antiga e grande teria uma alma velha. Uma pessoa boté precisaria rejuvenescer para casar.

Como mencionado, as coisas e as pessoas novas (yati) são consideradas bonitas. Já as velhas e antigas (boté) são vistas como feias, precisando ser substituídas, renovadas. O mesmo parece ser verdade para o contraste jovem/velho, sobretudo no nemê. Uma alma velha precisa rejuvenescer, e aqui o verbo utilizado é o namosá, que indica uma limpeza mas também um embelezamento. Parece-me, igualmente, que na velhice as pessoas perdem força e que o rejuvenescimento remete também a voltar a ter força. O namosá no nemê nos diz algo muito comum na vida cotidiana da aldeia: ninguém quer/gosta/seduz (nofá) o que ou quem é velho. Se a alma velha não rejuvenescesse, provavelmente não conseguiria se casar com uma linda e jovem pessoa-planta.

\section{A sedução}

O que chamo aqui de "sedução" vem do jarawara nofá, utilizado ao longo deste ensaio. O nofá aparece de diversas formas, em frases do tipo tiwa onofá okê, que seria algo como "eu gosto de você", "você pode ficar perto de mim", "você tem que cuidar de mim", "eu cuido de você", o que mostra um sentimento de carinho entrelaçado com cuidado. Ele pode ser visto igualmente em frases como bati hinofe, que remeteria a algo como o "pai dele gosta dele, quer criá-lo". Mas o nofá diz respeito também ao "ter vontade", yamá onofá okêre: "estou com preguiça, sem vontade de trabalhar". Quando alguém "se apaixona", explica-se assim: Soki nofá kê, "ela se apaixonou/foi seduzida/quer cuidar, estar com Soki". O "ter, estar com vontade" tem a ver com essa dimensão mais abrangente e englobadora do nofá, que traduzi por sedução. Ela sugere que grande parte das relações no mundo jarawara passa pela vontade: a vontade da pessoa e a vontade do outro, pois fazer o outro gostar de si, ter vontade de estar perto, de cuidar são também essenciais.

Essa "sedução/vontade" (nofá) manifesta-se nas diversas formas da criação e do cuidado que vimos: nos casamentos, na educação dos filhos, no cultivo do roçado. Os pais de criação devem, em um primeiro momento, mostrar que irão cuidar da criança que querem criar e da qual vão se aproximar gradualmente, fazendo com que ela se acostume e os escolha como pais. Quanto mais jovem a criança, mais ameno é esse processo. Inversamente, 
os pais verdadeiros devem cuidar de seus filhos, do contrário eles podem se deixar seduzir por outros pais potenciais. As pessoas precisam ter vontade de trabalhar no roçado para deixá-lo limpo/bonito, propício para que as plantas e suas almas nasçam. As almas de plantas levadas ao nemê são crianças, o que faz com que a criação por outros pais ocorra de forma extremamente singela. Em contraste, quando a alma dos mortos sai de seus corpos e é levada ao nemê, é preciso muita concentração e atenção. Seu primeiro impulso será retornar à sua aldeia, pois ela não sabe que morreu; caso isto aconteça, ela causará morte e sofrimento. Por isso, seus filhos-planta, avisados do falecimento pelo xamã, devem descer para convencê-la a ir com eles ao nemê. A alma sai brava e valente (hamaká) do corpo, querendo brigar. Traduzo aqui uma pequena parte da história que Wero me contou sobre seu primo, que mencionei no início deste ensaio:

"Cuidado, quando a alma do seu avô chegar, ela vai matar vocês" — o xamã falou (para as almas de tingui).

"Não, a alma do nosso avô não vai matar a gente, a gente vai cuidar (kakatomá) dela" - eles falaram.

Vemos que a sedução aqui é o aviso de cuidado futuro. Seduzir seria uma forma de mostrar um potencial de cuidar. Em uniões matrimoniais, o aviso deve ser dado sobretudo aos sogros potenciais, pois em geral são as mães que dão a palavra final em uma união, aprovando ou desaprovando a vontade de seus filhos de se casarem com alguém. Se a resposta for negativa, a união tem grandes chances de não ocorrer. Para casar certo (amosákê), deve-se sempre pedir à mãe ou ao pai do pretendido sua permissão. Os pais irão aceitar se o pretendente for um parente "certo" e se considerarem que ele "sabe trabalhar"/"tem força"/ "vontade para o trabalho", se pressentirem o potencial da pessoa para cuidar daquele ou daquela de quem cuidaram, mas também de cuidarem deles próprios — no presente e no futuro. Temos aqui uma sedução idêntica, mas simetricamente inversa à dos pais de criação: na primeira, os futuros pais seduzem o filho; na segunda (o casamento), o futuro genro ou nora deve seduzir os sogros. Se estes aceitarem, o "agregado" deverá, nos primeiros anos de casamento, passar bastante tempo na companhia deles e ajudá-los nas tarefas cotidianas, da mesma maneira que os filhos ajudam seus pais.

Se um homem se casa com uma mulher sem pedir aos pais dela e, consequentemente, sem os seduzir nem trabalhar para eles, trata-se de um roubo (boti), que remete ao carregar alguém: as mulheres que foram roubadas para se casar são também consideradas "carregadas" (weye, tiwana). 
Isto nos faz lembrar dos animais domésticos mencionados anteriormente, que são inicialmente carregados da floresta para a aldeia e depois criados amarrados (nawati). Este ato se assemelharia ao rapto de almas humanas por não humanos, em que a sedução é utilizada para enganar. O caso mais comum e sempre mencionado deste tipo de ação é a história de Siraba, uma jovem que viu um inamati sob a aparência de seu namorado e se deixou seduzir, tendo relações sexuais com ele na floresta. Na manhã seguinte a jovem morreu, pois seu amante era, na verdade, uma alma e levou-a para o nemê para se casar com ela.

Os seres que mais insistem em tentar se casar com os vivos são as almas de plantas jovens, muitas vezes chamadas de forma geral de inamati. São elas que rondam as aldeias ao escurecer e que na floresta aguardam a presença de alguém para, graças à aparência de um conhecido, seduzir a pessoa, roubar sua alma, levá-la para o nemê onde mora e se casar com ela. Esta gente-planta é normalmente composta por almas de plantas selvagens, ou então de roçados de desconhecidos. No entanto, não se descarta a possibilidade de que as almas das plantas do roçado (ou a dos mortos rejuvenescidos) tentem também seduzir seus cônjuges potenciais para levá-los para o nemê antes do tempo, causando suas mortes.

Além das almas de plantas, seres chamados yamá desejam se casar com as pessoas e roubam suas almas quando elas se encontram sozinhas na várzea ou na floresta. Eles se mostram sob a aparência de presa; se a pessoa acreditar, for seduzida, ela vai tentar caçar o animal, a relação então se inverte e são os yamá que raptam a alma humana. Eles podem também aparecer com o aspecto de um ente querido. Em todos os casos, enganam a pessoa para que o encontro ocorra e depois levam sua alma para onde moram, seguram-na alguns dias amarrada, o corpo da pessoa adoece, ela morre, e o yamá se casa com ela. Os yamá podem também decidir comer a pessoa; neste caso, não há ação possível para o xamã. Aqui, a sedução é utilizada como enganação e, em seguida, se torna agressão, como em uma caçada.

A sedução levaria tanto ao cuidar como ao devorar, passando pelo casar, que pode ser a expressão de um roubo (uma forma de carregar seguida por amarrar), de uma enganação ou de uma demonstração da capacidade de cuidar dos esposos e dos sogros. A vontade, o gostar (nofá), é aquilo que incita as pessoas a ficarem juntas e a cuidarem umas das outras, seduzindo-se cada vez mais. Mas é possível também que haja uma contraefetuação (Viveiros de Castro 2002) da sedução em um tipo de ação oposta: a predação. O importante aqui é perceber que a sedução não é apenas uma agência humana, ela é, por assim dizer, a agência acessível a todos os seres que compõem o mundo, podendo ser acionada por todos eles. Se é justamente esta "socia- 
lidade da sedução" que faz com que os Jarawara se casem, criem filhos, vivam juntos, queiram deixar "tudo bonito", é essa mesma socialidade que permite que eles sejam seduzidos por outros tipos de seres. Se o parentesco jarawara fosse um movimento, seria um movimento de sedução. Se ele fosse um domínio, seria aquele em que "cônjuges", "filhos", "plantas" e "mortos" seriam termos privilegiados para pensarmos os outros, ou "metáforas que participam umas nas outras" (Strathern 1988:188, tradução livre).

Procurei aqui discorrer sobre o "parentesco jarawara". "Criar" (nayana), "cuidar" (narifá) e "seduzir" (nofá) aparecem como conceitos etnográficos centrais para pensar o bem-estar das pessoas, o que as faz apreciar viverem juntas. É por seduzirem umas às outras que as pessoas se criam e se cuidam. É para namosá o mundo, para deixar tudo bonito, certo, renovado que elas vivem juntas. O namosá, ideia que revela aquilo que podemos definir como "parentesco", produz justamente os casamentos, a beleza cotidiana, o cultivo dos roçados, a construção de aldeias, a criação de crianças, o viver junto que configura essa "socialidade da sedução" jarawara, algo cuidadora, algo criadora. Por não se extinguir nas fronteiras da humanidade, esse processo é abarcado igualmente por relações com plantas cultivadas e seres celestes. Se, como mostrou Wagner (1991) ao discutir sobre "grandes-homens" na Melanésia, a "pessoa-fractal" é uma entidade cujas relações externas com outros são integrais e internas a ela, então aqui apontei que provavelmente os Jarawara são pais, cunhados, irmãos, tios, sogros, sobrinhos, netos, esposos, pais de plantas, irmãos de plantas, cunhados de plantas, filhos de plantas, sobrinhos de plantas, cônjuges potenciais de plantas - todos implicados em uma socialidade da sedução que visa deixar o mundo mais bonito, mais arrumado, amosákê. E estas são apenas algumas das relações...

Recebido em 07 de fevereiro de 2014

Aprovado em 28 de novembro de 2014

Fabiana Maizza é pós-doutoranda Fapesp na Universidade de São Paulo e pós-doutoranda associada ao Centre Enseignement et Recherche en Ethnologie Amérindienne, EREA, Paris. E-mail: <fabimaizza@hotmail.com> 


\section{Notas}

${ }^{1}$ Este artigo é fruto de um diálogo com as pessoas da aldeia Casa Nova, feito a partir de viagens subsidiadas, respectivamente, pelo CNPq (durante meu doutorado), pela bolsa de terrain Legs Lelong (CNRS/ França) e pela Fapesp, instituições às quais eu agradeço. Também agradeço a Uirá Garcia pela minuciosa leitura e pelos inúmeros comentários ao texto. A Laura Rival por sua generosidade em discutir este ensaio comigo, assim como a Marta Amoroso, Márcio Silva e Joana Cabral de Oliveira. Agradeço também a Tânia Stolze Lima e a Renato Sztutman pela oportunidade de participar do Grupo de Trabalho de Etnologia Indígena do $37^{\circ}$ Encontro Anual da Anpocs e por seus instigantes comentários, assim como pelos comentários de Els Lagrou e Elvira Belaunde na mesma ocasião. Finalmente, agradeço a Márcio Goldman e Karen Shiratori pelo convite para apresentar este ensaio no NAnSi (Museu Nacional/ UFRJ) e pelas sugestões de todos os presentes.

${ }^{2}$ Procurarei escrever as palavras na língua jarawara da forma como são pronunciadas, por isso utilizarei os acentos, que os Jarawara não usam ao escrever.

${ }^{3}$ Existiria uma divisão no mundo jarawara entre a Terra e "algo acima da Terra", que seria como uma "camada superior", um "céu", denominado nemê. O xamã teria acesso ao nemê, da mesma forma que os habitantes lá de cima desceriam regularmente para visitar o pajé. Peço gentilmente ao leitor e à leitora que guardem a palavra nemê, pois a utilizarei ao longo do ensaio, raramente voltando a traduzi-la.

${ }^{4}$ Anos depois dessa história, sonhei com uma "alma de tingui" (kona abono) que batia à porta de minha casa. Ela era um homem alto, com uma cabeça relativamente grande. Foi assim que consegui, enfim, entender e visualizar as plantas como gente, por mais que soubesse isso de forma abstrata.

${ }^{5}$ Utilizo a notação inglesa para as posições genealógicas: F para pai (father), M para mãe (mother) etc. Para quem fala português, é mais simples ler indo da direita para a esquerda, assim, FBD, por exemplo, é a "filha (D) do irmão (B) do pai (F)".

${ }^{6}$ Para um trabalho recente sobre o parentesco deni, ver Florido (2013).

${ }^{7}$ Mudarei alguns nomes e reduzirei outros, por se tratar de um assunto delicado para as pessoas.

${ }^{8}$ Deve-se levar em conta que em dois casos os pais de criação são simultaneamente a irmã da mãe (MZ) e o irmão do pai (FB). Em três casos, os irmãos do pai (FB e FZ) criam juntos a criança sem serem casados; o caso da esposa do pai aqui citado se refere ao novo cônjuge do pai; e, finalmente, esclareço que, nos casos colaterais, assumi a relação como equivalente à relação não colateral, por exemplo, considerei a prima paralela do pai (FMZD) irmã do pai (FZ). 
${ }^{9}$ Utilizei a tabela "Junções" do programa MaqPar (Máquina de Parentesco), concebida por Márcio Silva e João DalPoz, para verificar algumas relações da tabela. Agradeço também a Klaus Hamberger por sua ajuda no Atelier d'initiation au traitement informatique de la parenté 2013 (EHESS, Paris).

${ }^{10}$ No entanto, não se deve confundir aqui com os pais de criação ou pais adotivos dos Apinayé, que são também idealmente os irmãos de mesmo sexo de um dos pais (DaMatta 1976:118). O autor afirma que a paternidade biológica tem uma função distinta da paternidade social, encarnada pelos pais adotivos (:119), que são as "pontes" entre os pais biológicos e os nominadores de uma criança (:121-122). Coelho de Souza (2004) fez uma releitura das ideias de DaMatta, que não retomarei aqui, mas que apontam para o fato de que as relações de substância seriam também construídas.

${ }^{11}$ É preciso assinalar, no entanto, que os moradores do nemê são em sua maioria almas de plantas, mas não só. Existem também almas de facas/coisas de ferro e outras, que não discuto neste ensaio.

${ }^{12}$ Em um primeiro trabalho sobre este tema (Maizza 2012), afirmei que estas seriam clones. No entanto, Rival (2001:76) mostra que a própria ideia de clonagem deve ser repensada quando falamos de povos amazônicos. Hoje, tenho tendência a concordar com esta autora.

${ }^{13}$ Para mais comparações com o post-mortem dos grupos Arawá, ver Maizza (2012, capítulo 1); para uma análise recente sobre o destino póstumo Zuruahá, ver Suarez (2014).

${ }^{14}$ Nas mesmas linhas, Cohn (2000:83) afirma que a alma de uma criança xikrin que morre pequena é criança e deverá ser cuidada no post-mortem.

${ }^{15}$ A este propósito, Rival (2009:62) afirma que, entre os Huaorani, as plantas são nomeadas contextualmente de acordo com seu rebroto e estatuto de maturação e desenvolvimento físico. 


\section{Referências bibliográficas}

BONILLA, Oiara. 2005. "O bom patrão e o inimigo voraz: predação e comércio na cosmologia Paumari". Mana. Estudos de Antropologia Social, 11(1):41-66. - 2007. Des proies si desirables: soumisson et prédation pour les Paumari d'Amazonie brésilienne. Tese de Doutorado, École des Hautes Etudes en Sciences Sociales, Paris.

CARNEIRO DA CUNHA, Manuela. 1978. Os mortos e os outros. Uma análise do sistema funerário e da noção de pessoa entre os índios Krahó. São Paulo: Editora Hucitec.

CHAUMEIL, Bonnie \& CHAUMEIL, JeanPierre. 1992. "Loncle et le neveu. La parenté du vivant chezles Yagua (Amazonie péruvienne)". Journal de la Société des Américanistes, 1992, LXXVIII-II:25-37.

COELHO DE SOUZA, Marcela Stockler. 2004. "Parentes de sangue: incesto, substância e relação no pensamento Timbira". Mana. Estudos de Antropologia Social, 10(1):25-60.

COHN, Clarice. 2000. A criança indígena: a concepção xikrin de infância e aprendizado. Dissertação de Mestrado, Universidade de São Paulo.

COSTA, Luiz. 2007. As faces do jaguar. Parentesco, história e mitologia entre os Kanamari da Amazônia Ocidental. Tese de Doutorado, Museu Nacional/ UFRJ.

DAMATTA, Roberto. 1976. Um mundo dividido: a estrutura social dos índios Apinayé. Petrópolis: Editora Vozes.

DESCOLA, Philippe. 1986. La nature domestique. Symbolisme et praxis dans l'écologie des Achuar. Paris: Editions de la Maison des Sciences de L'Homme.

FAUSTO, Carlos. 2008. "Donos demais: maestria e domínio na Amazônia". Mana. Estudos de Antropologia Social, 14(2):329-366.
FLORIDO, Marcelo. 2013. Os Deni do Cuniuá: um estudo do parentesco. Tese de Doutorado, Universidade de São Paulo.

GARCIA, Uirá. 2010. Karawara: a caça e o mundo dos Awá-Guajá. Tese de Doutorado, Universidade de São Paulo.

GOW, Peter. 1997. "O parentesco como consciência humana: o caso dos Piro". Mana. Estudos de Antropologia Social, 3(2):39-65.

KROEMER, Gunter. 1994. Kunahã Made, o povo do veneno, sociedade e cultura do povo Zuruahá. Belém: Edições Mensageiro.

LÉVI-STRAUSS, Claude. 1949. Les structures élémentaires de la parenté. Paris: Presses Universitaires de France.

LIMA, Tânia Stolze. 1996. "O dois e seu múltiplo: reflexões sobre o perspectivismo em uma cosmologia tupi". Mana. Estudos de Antropologia Social, 2(2):21-47. .2002. "O que é um corpo?". Religião e Sociedade, 22(1):9-19. - 2005. Um peixe olhou para mim. O povo Yudjá e a perspectiva. São Paulo: ISA/ Editora Unesp/ NuTI.

MAIZZA, Fabiana. 2012. Cosmografia de um mundo perigoso. Espaço e relações de afinidade entre os Jarawara da Amazônia. São Paulo: Edusp/Nankin Editorial.

MATOS, Beatriz de Almeida. 2014. A visita dos espíritos: ritual, história e transformação entre os Matses da Amazônia brasileira. Tese de Doutorado, Museu Nacional/ UFRJ.

MCCALLUM, Cecilia. 1996. "Morte e pessoa entre os Kaxinawá". Mana. Estudos de Antropologia Social, 2(2):49-85.

OLIVEIRA, Joana Cabral de. 2012. Entre plantas e palavras. Modos de constituição de saberes entre os Wajãpi. Tese de Doutorado, Universidade de São Paulo. 
OVERING, Joana. 1975. The Piaroa: a people of the Orinoco Basin. Oxford: Oxford University Press.

. 1999. "Elogio do cotidiano: a confiança e a arte da vida social em uma comunidade amazônica". Mana. Estudos de Antropologia Social, 5(1):81-107.

. 1993. "Death and the loss of civilized predation among the Piaroa of the Orinoco Basin". L'Homme, tome 33, 126-128: 191-211 [La remontée de l'Amazone].

RIVAL, Laura. 2001. "Seed and clone: the symbolic and social significance of bitter manioc cultivation". In: L. Rival \& N. Whitehead (eds.), Beyond the visible and the material: the amerindianization of society in the work of Peter Rivière. Oxford, New York: Oxford University Press. pp. 57-79.

_ 2005. "The growth of family trees: understanding Huaorani perceptions of the forest". In: A. Surrallés \& P. García Hierro (eds.), The land within: Indigenous territory and the perception of environment. Copenhagen: IWGIA. pp. 90-109.

. 2009. "Towards and understanding of the Huaroani ways of knowing and naming plants". In: M. Alexiades (ed.), Mobility and migration in indigenous Amazonia: contemporary ethnoecological perspectives. New York: Berghahn Books. pp. 47-68.

SAHLINS, Marshall. 2011. "What kinship is (part one)". JRAI (NS), 17:2-19; "What kinship is (part two)", JRAI(NS), 17:227-42. SEEGER, Anthony, DAMATTA, Roberto \& VIVEIROS DE CASTRO, Eduardo. 1979. "A construção das pessoas nas sociedades indígenas brasileiras". Boletim do Museu Nacional, Série Antropologia, 32:2-19.

STRATHERN, Marilyn. 1988. The gender of the gift. Problems with women and problems with society in Melanesia. Berkeley: University of California Press. SUAREZ, Miguel Aparicio. 2014. Presas do timbó. Cosmopolítica e transfor- mações Suruwaha. Dissertação de Mestrado, Universidade Federal do Amazonas.

TAYLOR, Anne-Christine. 1998. "Jivaro kinship: "simple" and "complex" formulas: a dravidian transformation group". In: M. Godelier; T. Trautmann \& F. Tjon Sie Fat (eds.), Transformation of kinship. Washington, D.C.: Smithsonian Institution Press. pp. 187-213. . 2000. "Le sexe de la proie: représentations jivaro du lien de parenté". L'Homme, 154-155:309-334.

VILAÇA, Aparecida. 2005. "Chronically unstable bodies. Reflexions on Amazonian corporalities". The Journal of the Royal Anthropological Institute, 11(3):445-464.

VIVEIROS DE CASTRO, Eduardo. 1996. "Os pronomes cosmológicos e o perspectivismo ameríndio". Mana. Estudos de Antropologia Social, 2(2):115-144. . 1996b. "Ambos os três: sobre algumas distinções tipológicas e seu significado estrutural na teoria do parentesCo". Anuário Antropológico/95. Rio de Janeiro: Tempo Brasileiro. pp. 9-91. .2002. "Atualização e contraefetuação do virtual: o processo do parentesco". In: A inconstância da alma selvageme outros ensaios de antropologia. São Paulo: Cosac \& Naif. pp. 401-455. . 2002b. "Imanência do inimigo". In: A inconstância da alma selvagem -e outros ensaios de antropologia. São Paulo: Cosac \& Naif. pp. 265-294. - 2007. "Filiação intensiva e aliança demoníaca". Novos Estudos do Cebrap, 77:91-126.

WAGNER, Roy. 1981. The invention of culture. Chicago/ London: The University of Chicago Press. . 1991. "The fractal person". In: M. Godelier \& M. Strathern (orgs.), Big men and great men: personifications of power in Melanesia. Cambridge: Cambridge University Press. pp. 159-173. 


\section{Resumo}

As almas das plantas cultivadas pelos Jarawara saem de seus corpos quando pequenas e são criadas em aldeias no nemê, "camada superior", mas seriam filhas das pessoas que as cultivaram. $\mathrm{O}$ artigo propõe pensar o parentesco jarawara a partir das relações entre humanos e plantas em diálogo com as ideias de "pais de criação" e casamento. O fio condutor é o conceito namosá, uma forma de embelezar, consertar, transformar, rejuvenescer as relações e o cotidiano, ou uma estética do viver que se entrelaça com cuidado e sedução.

Palavras-chave Crianças, Plantas, Casamento, Parentesco, Jarawara.

\section{Abstract}

The souls of plants cultivated by the Jarawara come out of the bodies when they are young. They are nurtured in villages at the nemê, the upper layer, although they are the children of those who cultivate them. The article reflects on Jarawara kinship through the relations between humans and plants, in dialogue with the ideas of "nurturing parents" and marriage. Throughout the article, I focus on the concept of the namosá, a way to embellish, repair, transform and renew relations and everyday life, or an aesthetic of living that blends with care and seduction.

Key words Children, Plants, Marriage, Kinship, Jarawara. 